\title{
Integrin AlphaV/Beta3
}

National Cancer Institute

\section{Source}

National Cancer Institute. Integrin AlphaV/Beta3. NCI Thesaurus. Code C38953.

Involved in cell adhesion and signaling, human Integrin-aVBeta3 is composed of type I membrane protein chains Integ rin Alpha V (disulfide-linked heavy and light chains) and Integ rin Beta 3 that recognize RGD sequences. Multiple heterodimeric alpha/beta combinations result in different integrins. aV/beta-3 is a receptor for cytotactin, fibronectin, laminin, MMP-2, osteopontin, osteomodulin, prothrombin, thrombospondin, vitronectin, and von Willebrand factor. $(\mathrm{NCl})$ 